\title{
RELEVANSI TEORI MASLAHAT DENGAN UU PEMBERANTASAN KORUPSI
}

\author{
Asmawi \\ Dosen dan Ketua Program Studi Jinayah Siyasah Fakultas Syariah dan Hukum UIN \\ Syarif Hidayatullah, Jakarta. \\ Telepon: 081987654321 \\ Email:asma_wi@yahoo.com
}

\begin{abstract}
Aiming at protection of religion, soul, intelligence, wealth and progeny, the theory of maslahah permeates the norms of Corruption Eradication Law in Indonesia. The adoption of Islamic criminal law through the theory of maslahah into the system of national law means the transformation and objectivication of the former into the latter, which in turn reflects the integration of Islamic law into national law. The article argues that the application of the theory of maslahah on the criminalization of corruption, the formulation of sanctions on corruption, the concept of responsibility for corruption committted by the corporate, strongly indicates the process of islamization on special criminal law in Indonesia.

Bertujuan melindungi agama, jiwa, akal, harta dan keturunan, teori maslahah telah menjiwai norma yang terkandung dalam Undang-undang Pemberantasan Korupsi. Aplikasi hukum pidana Islam melalui teori maslahah dalam sistem hukum nasional mengimplikasikan adanya transformasi dan objektifikasi sistem hukum pertama ke dalam sistem hukum kedua, yang pada gilirannya mencerminkan integrasi keduanya. Artikel ini berargumen bahwa melalui penerapan teori maslahah dalam kriminalisasi korupsi, formulasi sanksi pidana korupsi, dan konsep pertanggungjawaban pidana korporasi jelas menunjukkan terjadinya proses islamisasi dalam perundang-undangan pidana khusus di Indonesia.
\end{abstract}

\section{Keywords:}

\section{Pendahuluan}

Kebijakan legislasi-sebagai elemen penting tata hukum pidana nasional-pada era reformasi yang menarik untuk dicatat ialah pengesahan dan pemberlakuan perundangundangan pidana khusus, yakni UU Pemberantasan Korupsi. Undang-undang ini merupakan manifestasi dari tata hukum pidana nasional pada masa reformasi ini.

Tata hukum pidana nasional tersebut menjadi menarik untuk dikaji jika dihubungkan dengan teori maslahat sebagai kerangka acuan legislasi hukum pidana Islam. Pengkajian maslahat menjadi sangat urgen jika dikaitkan dengan upaya menemukan relevansi maslahat tersebut dengan perundang-undangan pidana nasional di atas. Di samping itu, agar hukum pidana Indonesia senantiasa mampu menyesuaikan diri dengan perkembangan keadaan maka membuka diri dan menerima unsur-unsur luar yang relevan merupakan suatu keharusan, termasuk perihal penyerapan hukum pidana Islam (sebagai hukum agama) melalui aplikasi maslahat.

Pengkajian relevansi teori maslahat dengan perundang-undangan pidana khusus di Indonesia juga harus diletakkan dalam 
perspektif usaha pembaharuan hukum pidana Indonesia. Dalam hal ini, perlu dikaji sejauhmana teori maslahat terimplementasi dalam berbagai ketentuan perundangundangan pidana nasional tersebut, terutama menyangkut aspek kriminalisasi, aspek formulasi sanksi pidana, dan aspek pertanggungjawaban pidana korporasi. ${ }^{1}$

Pengkajian tersebut tentu sangat penting untuk mengeksaminasi tata hukum pidana nasional, yakni apakah ia sudah islami lantaran sudah menyerap hukum pidana Islam melalui aplikasi teori maslahat ataukah justru sebaliknya?; apakah hukum pidana Islam sudah mengalami transformasi-melalui aplikasi teori maslahat-ke dalam tata hukum pidana nasional, yang sebagian direpresentasikan oleh perundang-undangan pidana nasional berupa UU Pemberantasan Korupsi? Alih-alih berpolemik seputar penegakan syariah Islam yang sarat dengan nuansa kontroversial, pengkajian tentang relevansi teori maslahat dengan perundangundangan pidana nasional memiliki nilai signifikan dan kontributif bagi upaya implementasi hukum pidana Islam dalam konteks keindonesiaan sekaligus kemodernan, yang secara substantif juga bermakna sebagai penegakan Syariat Islam. Lebih jauh, dapatlah dikatakan bahwa tantangan terbesar umat Islam dalam gegap gempitanya upaya penerapan Syariat Islam adalah memperjelas hal-hal yang berkaitan dengan hukum pidana Islam; dan ini menuntut kajian yang mendalam seputar hukum pidana Is lam, yang salah satunya ialah pengkajian tentang transformasi hukum pidana Islam ke dalam hukum pidana nasional melalui aplikasi maslahat.

Fokus masalah tulisan ini berkisar pada masalah ide relevansi teori maslahat dengan perundang-undangan pidana khusus di Indonesia. Dengan demikian, dalam tulisan ini yang dijadikan masalah pokok ialah

${ }^{1}$ Chairul Huda, " Dari 'Tiada Pidana Tanpa Kesalahan' Menuju Kepada 'Tiada Pertanggungjawaban Pidana Tanpa Kesalahan“ “ (Tinjauan Kritis terhadap Teori Pemisahan Tindak Pidana dan Pertanggungjawaban Pidana), (Jakarta: Kencana Prenada Mulia, 2006), h. 10. bagaimanakah konstruksi-teoretis maslahat dan bagaimanakah relevansi ${ }^{2}$ teori maslahat itu dengan perundang-undangan pidana khusus di Indonesia, yang direpresentasikan oleh UU Pemberantasan Korupsi dan bagaimanakah implikasi dari adanya relevansi tersebut.

\section{Formulasi Teori Maslahat}

Menyangkut "formulasi teori maslahat" dapat disajikan sebagai berikut. Maslahat merupakan tujuan yang dikehendaki oleh alSyâri' dalam hukum-hukum yang ditetapkanNya melalui teks-teks suci Syariah (nuŝûs alsyarî'ah) berupa al-Qur'an dan Hadis. Tujuan tersebut mencakup 6 (enam) hal pokok, yaitu perlindungan terhadap agama, perlindungan terhadap jiwa, perlindungan terhadap akal budi, perlindungan terhadap keturunan, perlindungan terhadap kehormatan diri, dan perlindungan terhadap harta kekayaan. Maslahat itu bertingkat-tingkat, yakni darûriyyât, hâjjiyyât dan tahsîniyyât. Sesuatu yang mampu menjamin eksistensi masingmasing dari keenam hal pokok itu merupakan maslahat pada tingkat darûriyyât. Sesuatu yang mampu memberi kemudahan dan dukungan bagi penjaminan eksistensi masing-masing dari keenam hal pokok itu merupakan maslahat pada tingkat hâjjiyyât. Sesuatu yang mampu memberi keindahan, kesempurnaan, keoptimalan bagi penjaminan eksistensi masing-masing dari keenam hal pokok itu merupakan maslahat pada tingkat tahsîniyyât.

Maslahat itu mencakup 2 (dua) unsur yang padu dan holistik, yakni jalb almanâfi'/al-masâlith wa dar' al-mafâsidlalmadârr yang mengandung arti "mewujudkan sesuatu yang bermanfaat/baik atau yang membawa kemanfaatan/kebaikan, dan mencegah serta menghilangkan sesuatu yang negatif-destruktif atau yang membawa kerusakan/mudarat, di mana hal ini semua tetap dalam kerangka arahan al-Qur'an dan

2 Secara leksikal-etimologis, kata "relevansi" mengandung arti: hubungan, kaitan. Lihat Pusat Bahasa-Depdiknas, Kamus Besar Bahasa Indonesia, (Jakarta: Balai Pustaka, 20005), Edisi Ketiga, hlm. 943. 
Hadis. Dalam hal ini, perlu dipertimbangkan segi yang menyangkut kepentingan individual/terbatas (al-maslahah al-khâssah) dan kepentingan umum/masyarakat luas (almaslahah al- 'âmmah), dan prioritas diberikan kepada kepentingan umum/masyarakat luas. Maslahat yang terdapat di dalam nass-nass dapat dipahami dengan meneliti kandungan makna nass-nass itu. Di sini perlu diterapkan langkah "interpretasi berorientasi-maslahat terhadap nass" (al-tafsîr al-maslahiy li al-

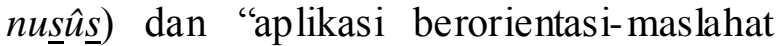
terhadap nass" (al-tatbî̀q al-mas lahiy li alnus $\underline{\hat{u}} \underline{\mathrm{s}}$.

Dalam menghadapi kasus/masalah yang tidak ditentukan hukumnya secara eksplisit oleh nass yang spesifik, perlu merujuk kepada nass yang bersifat umum, diiringi dengan langkah "interpretasi berorientasimaslahat terhadap nass" dan "aplikasi berorientasi-maslahat terhadap nass". Di samping itu, maslahat dapat ditemukan dan diaplikasikan: (1) melalui penerapan analisis jalb al-manâfi'/al-masâlih wa dar' almafâsidlal-madârr; (2) melalui penerapan metode/dalil Syara' sekunder seperti al-qiyâs, al-maslahah al-mursalah, sadd al-dzarî'ah, dan al-'urf.; dan (3) melalui penerapan alqawâ id al-fiqhiyyah (Islamic legal maxims). Dalam konteks ini, upaya mengkualifikasi sesuatu sebagai maslahat harus mengacu kepada parameter nass yang berupa garisgaris besar haluan nass sehingga terhindar dari kesimpulan hukum yang kontradiktif dengan $n a \underline{s}$.

\section{Maslahat: Titik Temu Hukum Agama dan Hukum Negara}

Dalam pandangan Abdullahi Ahmed An-Na'im, hukum Islam hanya bisa dipromosikan dan diterapkan melalui adaptasi dengan kebutuhan masyarakat Islam modern. Akan tetapi, betapapun akomodasi prinsip-prinsip hukum Islam dalam legislasi hukum negara modern tetap saja dilakukan melalui proses yang sekular, dan ia bukan merupakan legislasi langsung prinsip-prinsip hukum Islam itu sendiri. ${ }^{3}$ Jelasnya, melalui

3 Abdullahi Ahmed An-Na'im, Islam dan Negara Sekuler: Menegosiasikan Masa Depan legislasi, hukum Islam telah bergeser dari otoritas hukum agama (divine law) menjadi otoritas hukum negara (state law). ${ }^{4}$

Menurut pandangan Denny J.A., hukum Islam itu berada pada titik tengah antara paradigma agama dan paradigma negara. Sebagai bagian dari paradigma agama Islam, penerapan hukum Islam menjadi misi agama, dan ini menuntut operasionalisasi hukum Islam dalam realitas-empiris. Namun, pada saat yang sama hukum Islam pun menjadi bagian dari paradigma negara yang mempunyai sistemnya sendiri yang nota bene diselimuti oleh konteks pluralitas yang menuntut adanya netralitas (tidak berpihak pada salah satu agama) sehingga mau tak mau negara mereduksi hukum Islam demi komitmen atas pluralitas itu sehingga penganut agama lain merasa tidak terancam. Konsekuensinya, masalah penerapan hukum Islam menjadi rumit karena hukum Islam itu berada di domain agama dan domain negara sekaligus, dalam lingkar tarik-menarik antara prinsip agama dan prinsip negara. ${ }^{5}$

Lebih lanjut, Denny J.A. menjelaskan bahwa tarik-menarik doktrin agama dan doktrin negara dapat diselesaikan dengan pembagian domain. Untuk hukum yang bersifat publik diberlakukan hukum negara. Tentu saja dalam perumusan hukum publik itu, negara dapat mengambil inspirasi nilai/norma dari manapun, termasuk hukum Islam. Namun, nilai itu telah diuniversalkan melampui batas keagamaan itu send iri. ${ }^{6}$

Eksistensi hukum Islam di Indonesia selalu mengambil 2 (dua) bentuk, yaitu (1) hukum normatif yang diimplementasikan secara sadar oleh umat Islam; dan (2) hukum formal yang dilegislasikan sebagai hukum positif bagi umat Islam. Yang pertama

Syariah, terj. Sri Murniati, (Bandung: Penerbit Mizan, 2007), hlm. 36-37.

${ }^{4}$ Siti Musda Mulia, dkk, Pembaruan Hukum Islam: Counter Legal Draft Kompilasi Hukum Islam, (Jakarta: Tim Pengarusutamaan Gender, Departemen Agama, 2004), hlm. 12.

5 Denny J.A., “ Legislasi Hukum Islam dan Integrasi Nasional ", dalam PESANTREN No. 2/Vol. VII/1990, hlm. 3.

6 Denny J.A., “ Legislasi Hukum Islam dan Integrasi Nasional “, hlm. 3. 
menerapkan pendekatan kultural, sedang yang kedua mengutamakan penghampiran struktural. Hukum Islam dalam bentuk kedua itupun proses legislasinya menggunakan 2 (dua) cara. Pertama, hukum Islam dilegislasikan secara formal untuk umat Islam, seperti PP No. 28 Tahun 1977, UU No. 17 Tahun 1999, dan UU No. 38 Tahun 1999. Kedua, materi-materi hukum Islam diintegrasikan ke dalam hukum nasional tanpa menyebutkan hukum Islam secara formal, seperti UU No. 1 Tahun 1974 dan UU No. 7 Tahun $1989 .^{7}$

Menurut pendapat Ichtijanto SA, hukum agama merupakan unsur mutlak hukum nasional. Tertib hukum masyarakat Indonesia membutuhkan adanya peraturan perundang-undangan yang sesuai dengan dan bersumber dari ajaran-ajaran agama. Sumber tertib hukum negara RI ialah pandangan hidup, kesadaran dan cita hukum serta cita moral yang meliputi suasana kejiwaan dan watak bangsa Indonesia yang religius. ${ }^{8}$

Dalam perbincangan implementasi hukum Islam di Indonesia, patut juga diperhatikan tawaran paradigma Kuntowijoyo, yakni paradigma obyektivikasi Islam. Objektivikasi hukum Islam $^{9}$ tetap memposisikan al-Qur'an sebagai sumber hukum. Objektivikasi hukum Islam akan menjadikan hukum al-Qur'an terlebih dahulu sebagai hukum positif, yang pembentukannya atas persetujuan bersama warga negara. Jadi, tidak secara langsung dan otomatis seluruh norma hukum Islam menjadi hukum negara, tetapi ia harus melalui objektivikasi. Dalam wadah pembentukan hukum positif itulah dipertemukan obyektivikasi dari berbagai hukum agama: Islam, Katholik, Protestan, Hindu, dan Budha, serta hukum-hukum lain.

${ }^{7}$ Siti Musda Mulia, dkk, Pembaruan Hukum Islam: Counter Legal Draft Kompilasi Hukum Islam, (Jakarta: Tim Pengarusutamaan Gender, Departemen Agama, 2004), hlm. 8.

8 Ichtijanto SA, Hukum Islam dan Hukum Nasional, (Jakarta: Ind-Hill co Indonesia, 1990), hlm. 50 .

9 Dalam pandangan penulis, paradigma objektivikasi Islam relevan dengan persoalan implementasi hukum Islam, sehingga layak disebut dengan "paradigma objektivikasi hukum Is lam".
Dengan objektivikasi akan terjamin kesamaan/persamaan di dalam hukum antaragama sehingga meredakan ancaman terhadap stabilitas nasional. Karena itu, ungkapan "menghukumi dengan hukum Allah" itu juga harus di-objektivikasi-kan dalam sejumlah peraturan perundangundangan. Umat Islam menghendaki objektivisme, bukan sekularisme. ${ }^{10}$ Objektivikasi merupakan paradigma berpikir yang bertolak dari abstrak ke konkret, dari ideologi ke ilmu, dan dari subjektif ke objektif. ${ }^{11}$

Dalam pandangan penulis, objektivikasi hukum Islam dapat ditemukan basisteoretisnya pada teori maslahat. Ahmad Munif Suratmaputra menyimpulkan bahwa dalam menghadapi masalah baru yang timbul di tengah kehidupan masyarakat, aplikasi teori maslahat merupakan metode ijtihad yang paling tepat; dan ini telah dipratikkan dalam sekian banyak ijtihad para Sahabat Nabi, ulama al-tâbi în dan para imam mazhab. Agenda pembaharuan hukum Islam harus mereposisi aplikasi teori maslahat sebagai formula utama. ${ }^{12}$ Yudian Wahyudi menilai bahwa aplikasi teori maslahat sebenarnya merupakan metode yang luar biasa untuk mengembangkan nilai dan ruh hukum Islam ke dalam berbagai masalah. Pengembangan teori ini secara tajam dan bertanggung jawab merupakan kebutuhan yang tidak bisa ditunda-tunda lagi agar umat Islam tidak menjadi umat yang berwawasan sempit dan kerdil. ${ }^{13}$ Hasbi Asshiddiqiey mengkonstatir bahwa norma-norma Syariah di bidang muamalah dapat dijangkau daya analisis akal budi sehingga dapat dipahami

${ }^{10}$ Kuntowijoyo, Identitas Politik Umat Islam, (Bandung: Mizan, 1999), hlm. 69-70.

11 Uraian lebih jauh, lihat Kuntowijoyo, Identitas Politik Umat Islam, (Bandung: Mizan, 1999), hlm. 17, 20 dan 23.

12 Ahmad Munif Suratmaputra, Filsafat Hukum Islam al-Ghazali: Maslahat Mursalah \& Relevansinya dengan Pembaharuan Hukum Islam, (Jakarta; Pustaka Firdaus, 2002), hlm. 185. Buku ini semula merupakan disertasi doktor penulisnya.

13 Yudian Wahyudi, Ushul Fikih versus Hermenutika: Membaca Islam dari Kanada dan Amerika, (Yogyakarta: Pesantren Nawesea Press, 2006), hlm. 51-52. 
maqâsid al-tasyrî́'-nya, dengan panduan prinsip jalb al-masâlih dan dar' al-mafâsid, di mana segala yang mengandung atau membawa kepada maslahat adalah mubâh ; dan sebaliknya, segala yang mengandung atau membawa kepada al-mafsadah adalah haram. $^{14}$ Munawir Sjadzali menyimpulkan bahwa maslahat dan keadilan merupakan tujuan syari'at Islam, dan keadilan merupakan dasar maslahat. ${ }^{15}$ Senada dengan Munawir Sjadzali, Masdar F. Mas'udi menggulirkan tesis bahwa hukum Islam tidak bisa didasarkan kecuali kepada sesuatu yang tidak disebut hukum, sesuatu yang melampui hukum (meta-hukum), yakni sistem nilai berupa maslahat dan keadilan sehingga sangat relevan untuk ditegakkan adagium "

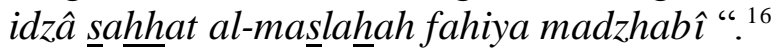

Dari uraian di atas dapat disimpulkan bahwa integrasi hukum Islam ke dalam hukum negara punya pilihan jalan strategis yang jauh dari resistensi sosial-politik, dan jalan dimaksud ialah aplikasi maslahat dalam bingkai transformasi/objektivikasi hukum Islam ke dalam tatanan hukum negara.

\section{Relevansi Maslahat dengan UU Pemberantasan Korupsi}

Bagian ini menyajikan bahasan tentang relevansi maslahat dengan UU Pemberantasan Tindak Pidana Korupsi, yakni UU RI No. 20 Tahun 2001 tentang Perubahan atas UU No. 31 Tahun 1999 tentang Pemberantasan Tindak Pidana Korupsi, dan UU No. 31 Tahun 1999 tentang Pemberantasan Tindak Pidana Korupsi. Dalam bab ini dianalisis 3 (tiga) aspek utama, yaitu (1) norma-norma kriminalisasi, (2) norma-norma formulasi sanksi pidana, dan (3) norma-norma konsepsi

14 Hasbi Asshiddiqiey, Pengantar Hukum Islam, (Jakarta: Bu lan Bintang, 1981), Jilid 2, h. 80.

15 Munawir Sjadzali, " Reaktualisasi Ajaran Islam “, dalam Iqbal Abdurrauf Saimima, (ed.), Polemik Reaktualisasi Ajaran Islam, (Jakarta: Pustaka Panjimas, 1988), h. 50.

${ }^{16}$ Masdar F. Mas'udi, “ Meletakkan kembali Maslahah sebagai Acuan Syariat “, dalam Zuhairi Misrawi, Menggugat Tradisi: Pergulatan Pemikiran Anak Muda NU, (Jakarta: Penerbit Buku Kompas, 2004), hlm. 57 dan 62. pertanggungjawaban pidana korporasi, di mana norma-norma tersebut diwadahi oleh sejumlah pasal. Dalam kaitan ini, digunakan pisau analisis teori maslahat. Indikator "relevansi" dalam uraian analisis ini ialah tingkat aplikasi maslahat dalam setiap norma yang dianalisis.

\section{Aplikasi Maslahat dalam Kriminalisasi}

Dalam sub-bagian ini, analisis difokuskan pada aplikasi maslahat dalam kriminalisasi, di mana hal terdiri atas: "aplikasi maslahat dalam kriminalisasi korupsi", dan "aplikasi maslahat dalam kriminalisasi perbuatan lain yang berkaitan dengan tindak pidana korupsi”. Masingmasing norma yang mengaturnya akan dianalisis dengan optik teori maslahat.

Uraian tentang "aplikasi maslahat dalam kriminalisasi korupsi” mencakup 7 (tujuh) macam kualifikasi korupsi yang menjadi wadah diaplikasikannya maslahat. Ketujuh macam itu ialah kualifikasi korupsi terkait keuangan/perekonomian negara, kualifikasi korupsi terkait suap-menyuap, kualifikasi korupsi terkait penggelapan dalam jabatan, kualifikasi korupsi terkait pemerasan, kualifikasi korupsi terkait perbuatan curang, kualifikasi korupsi terkait benturan kepentingan dalam pengadaan, dan kualifikasi korupsi terkait gratifikasi.

$$
\text { Perihal "korupsi terkait }
$$
keuangan/perekonomian negara" diatur dalam Pasal 2 dan Pasal 3 UU No. 31 Tahun 1999. Dalam kasus kriminalisasi Pasal 2 ayat (1) dan Pasal 3 di atas-yang nota bene varian dari al-gulûl dan akl al-suht sekaligus merupakan al-ma śsiyyah-tentu punya dasar rasionalitas, yang dapat dikemukakan sebagai berikut. ${ }^{17}$ Pertama, perbuatan yang dikriminalisasi Pasal 2 ayat (1) dan Pasal 3 jelas melahirkan efek buruk bagi perekonomian negara lantaran tergerogotinya pendapatan negara dari sektor publik dan

${ }^{17}$ Diperhatikan pula konsiderans "Menimbang" UU No. 31 Tahun 1999 tentang Pemberantasan Tindak Pidana Korupsi, dan konsiderans "Menimbang" UU RI No. 20 Tahun 2001 tentang Perubahan atas UU No. 31 Tahun 1999 tentang Pe mberantasan Tindak Pidana Korupsi. 
membengkaknya pembelanjaan pemerintah untuk sektor publik. Kedua, perbuatan yang dikriminalisasi Pasal 2 ayat (1) dan Pasal 3 jelas melahirkan iklim ekonomi berbiaya tinggi (high cost economy). Ketiga, perbuatan yang dikriminalisasi Pasal 2 ayat (1) dan Pasal 3 jelas menimbulkan kerugian bagi negara yang pada gilirannya menghambat gerak laju pembangunan guna tercapainya kesejahteraan rakyat. Ketiga hal yang menjadi dasar rasionalitas inilah yang menggambarkan adanya aplikasi maslahat dalam kriminalisasi Pasal 2 ayat (1) dan Pasal 3.

Lebih dari itu, dengan melihat unsur "dapat merugikan keuangan/perekonomian negara" pada kualifikasi tindak pidana korupsi tersebut, aplikasi maslahat berupa jalb al-manâfi' dan dar 'al-mafâsid terlihat jelas dalam hal ini. Dampak "kerugian/perekonomian negara" yang ditimbulkan oleh perbuatan korupsi sangat dahsyat sekali, baik menyangkut perekonomian mikro maupun perekonomian makro. Pada tataran perekonomian mikro, dampak yang ditimbulkan oleh korupsi ialah (a) semakin menurunnya kualitas taraf hidup rakyat; (b) semakin sulitnya upaya masyarakat memperoleh pendapatan ekonomi; (c) semakin meningginya pola pengeluaran masyarakat; (d) semakin buruknya tingkat kesehatan masyarakat lantaran semakin menurunnya pola pengeluaran konsumsi untuk kesehatan; dan (e) semakin menurunnya kinerja sektorsektor produksi, distribusi dan industri. Sedangkan pada tataran perekonomian makro, korupsi melahirkan dampak-dampak yang hebat, yakni (a) semakin merosotnya pertumbuhan ekonomi nasional; (b) semakin tingginya tingkat inflasi; (c) semakin rendahnya kinerja investasi nasional; (c) semakin merosotnya nilar tukar mata uang Rupiah; dan (d) semakin rendahnya kinerja perbankan nasional. ${ }^{18}$ Upaya-upaya yang ditujukan untuk mencegah dan

${ }^{18}$ Mengenai uraian lebih rinci tentang dampak korupsi terhadap keuangan negara/perekonomian negara, lihat Muljatno Sindhudarmoko, dkk, Ekonomi Korupsi, (Jakarta: Pustaka Quantum, 2001). menanggulangi "kerugian keuangan /perekonomian negara" itu merupakan konkretisasi maslahat berupa jalb al-manâfi ${ }^{6}$ dan dar' al-mafâsid. Jadi, terkandung substansi jalb al-manâfi ' wa dar 'al-mafâsidyang nota bene unsur maslahat) dalam kriminalisasi Pasal 2 ayat (1) dan Pasal 3.

Sementara itu, Pasal 2 ayat (2) UU No. 31 Tahun 1999 jo. UU No. 20 Tahun 2001 mengatur perihal faktor pemberatan pidana terkait tindak pidana korupsi versi Pasal 2 ayat (1). Faktor pemberatan dimaksud ialah (a) tindak pidana korupsi dilakukan terhadap dana yang diperuntukkan bagi penanggulangan keadaan bahaya; (b) tindak pidana korupsi dilakukan terhadap dana yang diperuntukkan bagi penanggulangan bencana alam nasional; (c) tindak pidana korupsi dilakukan terhadap dana yang diperuntukkan bagi penanggulangan akibat kerusuhan sosial yang meluas; (d) tindak pidana korupsi dilakukan terhadap dana yang diperuntukkan bagi penanggulangan krisis ekonomi dan moneter; atau (f) tindak pidana korupsi dilakukan sebagai pengulangan tindak pidana. Telah dikemukakan bahwa dalam perspektif hukum pidana Islam, Pasal 2 ayat (1) merupakan domain kriminalisasi ta' $z \hat{\imath} r$ sehingga Pasal 2 ayat (2) pun juga masuk dalam cak upan kriminalisasi $t a$ ' $z \hat{\imath} r$.

Dalam perspektif hukum pidana Islam, sejauh dalam lingkup kriminalisasi ta' $z \hat{\imath} r$, pidana mati memang dimungkinkan untuk ditetapkan/dijatuhkan bagi tindak pidana tertentu yang sangat dahsyat efek destruksinya. Meskipun demikian, pidana mati sebagai sanksi pidana ta'zîr tetap diperselisihkan oleh para ulama fikih, di mana sebagian ulama tidak membolehkan secara mutlak penerapan pidana mati sebagai sanksi pidana ta'z $\hat{\imath} r$ dan sebagian lagi melegitimasi pidana mati sebagai sanksi pidana ta'zîr dengan persyaratan tertentu, antara lain, kedahsyatan efek destruksi yang ditimbulkannya dan keadaannya sebagai pengulangan tindak pidana (recidive). ${ }^{19}$ Dalam kaitannya dengan Pasal 2 ayat (2) di

${ }^{19}$ Lihat Muhammad 'Ali ibn Sinân, al-Jânib alTa 'zîriy fi Jarîmat al-Zina, (t.tp: t.np. , 1402 H/1982 M), hlm. 76-79. 
atas, terdapat persyaratan khusus yang harus dipenuhi suatu perbuatan korupsi untuk dijatuhi pidana mati, di mana persyaratan tersebut memenuhi kriteria kedahsyatan efek destruksi yang ditimbulkannya dan keadaannya sebagai pengulangan tindak pidana (recidive). Dengan demikian, di dalam Pasal 2 ayat (2) UU No. 31 Tahun 1999 jo. UU No. 20 Tahun 2001 telah terkandung aplikasi maslahat berupa jalb al-manâfi dan dar' al-mafâsid.

Perihal "korupsi terkait suapmenyuap" diatur dalam Pasal 5 ayat (1) huruf a, Pasal ayat (1) huruf b, Pasal 13, Pasal 5 ayat (2), Pasal 12 huruf a, Pasal 12 huruf b, Pasal 11, Pasal 6 ayat (1) huruf a, Pasal 6 ayat (1) huruf b, Pasal 6 ayat (2), Pasal 12 huruf c, dan Pasal 12 huruf d.

Dalam perspektif hukum Islam, tindakan suap-menyuap (al-risywah)-di dalam al-Qur'an dan Hadis-jelas diharamkan dan dikategorikan sebagai al-ma śiyyah. ${ }^{20} \mathrm{Hal}$ ini merujuk kepada Q.S. al-Baqarah/2:188 dan Hadis Abû Dâwud tentang larangan suap-menyuap (al-risywah). ${ }^{21}$ Karena itu, ia dapat dikriminalisasi dengan kategori kriminalisasi ta 'zîr.

Dari sudut kualifikasi pelaku dalam korupsi terkait suap-menyuap sebagaimana dinyatakan dalam Pasal-pasal di atas, terdapat 5 (lima) tipe pelaku korupsi aktif (suapmenyuap), yaitu (a) orang, yang mencakup orang perseorangan dan korporasi, (b) pegawai negeri, (c) penyelenggara negara, (d) hakim, dan (e) advokat; dan ada 4 (empat) tipe pelaku korupsi pasif (suap-menyuap), yakni semua yang telah disebutkan kecuali orang (yang mencakup orang perseorangan dan korporasi). Dengan adanya ketentuan tersebut semakin sempit ruang berkilah dan

20 Bandingkan dengan Keputusan Muktamar XXXI Nahdlatul Ulama dalam Sekretariat Jenderal PB Nahdlatul Ulama, Hasil-Hasil Muktamar XXXI Nahdlatul Ulama, (Jakarta: Setjen PB NU, 2005), hlm. 133-137.

21 Hadis ini diriwayatkan oleh Abû Dâwud, yang bersumber dari 'Abdullah ibn 'Amr. Lihat Abû Dâwud Sulaimân ibn al-Asy'as al-Sijistani, Sunan Ab̂̀ Dâwud, Juz ke-10, hlm. 444, Hadis No. 3582. Su mber diakses dari DVD Program al-Maktabah al-Syâmilah, Versi 2.11, Edisi Kedua. berkelit orang-orang yang terlibat peristiwa korupsi, di mana seringkali perihal posisi pasif orang bersangkutan dan perihal bukan pegawai negeri dijadikan celah untuk lari dari jeratan hukum. Upaya mempersempit ruang gerak aktor korupsi itu jelas bertujuan demi terwujudnya efektivitas hukum yang optimal sehingga program pemberantasan korupsi yang dijalankan mampu mencapai hasil yang diharapkan rakyat, yakni masyarakat bangsa yang nir-korupsi. Jadi, di dalam kriminalisasi kedua belas pasal itu mengandung makna jalb al-masâalih wa dar' al-mafâsid. Ini berarti manifestasi dari maslahat yang terkandung dalam keseluruhan konstruksi 12 (dua belas) pasal tersebut.

Dari sudut pandang teori maslahat, konstruksi keduabelas pasal itu merepresentasikan aplikasi maslahat, yang diantaranya berupa penyerapan beberapa legal maxim hukum Islam ${ }^{22}$, yakni "la darar wa la dirâr"'(tidak boleh mendatangkan bahaya/kerusakan terhadap diri sendiri dan tidak boleh pula mendatangkan bahaya/kerusakan terhadap orang lain.), "aldarar yuzâl" (segala bahaya/kerusakan harus dicegah/diberantas) dan "yutahammal al-

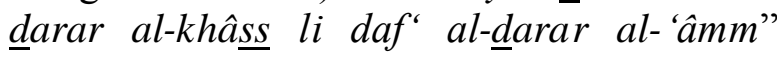
(bahaya/kerusakan yang terbatas/spesifik dapat ditoleransi karena demi menghindari/memberantas bahaya/kerusakan yang meluas). ${ }^{23}$ Efek destruksi dari tindakan korupsi berupa suap-menyuap memang sangat hebat. Tindakan demikian mengakibatkan ekonomi biaya tinggi (high cost economy), di samping raibnya harta kekayaan negara yang sangat besar

22 Adanya keterkaitan substantif antara maslahat dan al-Qawâ id al-Fiqhiyyah telah diulas oleh kalangan pemikir hukum Islam. Lihat Muhammad Kamâl al-Dîn Imâm, Nażariyyat al-Fiqh fi al-Islâm: Madkhal Manhajiy, (Beirut: al-Mu'assasah al-Jâmi 'iyyah li al-Dirâsât wa al-Nasyr wa al-Tauzî', 1418 H/1998 M), hlm. 181.

23 Mengenai uraian mendalam tentang legal maxim in i, lihat 'Ali Ah̆mad al-Nadwiy, al-Qawâ'id al-Fiqhiyyah: Mafhûmuhâ, Nasy'atuhâ, Tatawwuruhâ, Dirâsat Mu'allafâtihâ, Adillatuhâ, Muhimmatuhâ, Tațbîâtuhâ, (Damaskus: Dâr al-Qalam, 1414 H/1994 M), hlm. 286-293. Karya ini semula merupakan disertasi penulisnya pada Program Doktor Universitas Umm al-Qurâ, Mekkah, Arab Saudi. 
jumlahnya. Pelaku korupsi demikian telah menilap harta kekayaan negara yang semula direncanakan untuk pembangunan kesejahteraan rakyat. Dampak desktruksi korupsi demikian menjalar ke seluruh sendi kehidupan negara, di antaranya sendi perekonomian mikro, sendi perekonomian makro, dan sendi perekonomian perbankan dari negara, dan bahkan sendi perekonomian internasional. ${ }^{24}$ Kandungan makna sejumlah legal maxim hukum Islam tersebut telah diakomodasi melalui konstruksi 12 (dua belas) Pasal tersebut, dan karenanya maslahat telah teraplikasikan dalam upaya memberi dasar rasionalitas kualifikasi korupsi dalam keduabelas pasal itu.

Perihal 'korupsi terkait penggelapan dalam jabatan" diatur dalam Pasal 8, Pasal 9, Pasal 10 huruf a, Pasal 10 huruf $\mathbf{b}$, dan Pasal 10 huruf c. Dalam perspektif hukum Islam, "korupsi terkait penggelapan dalam jabatan" yang diatur dalam 5 (lima) pasal dapat diidentifikasi dengan merujuk kepada masalah al-gulûl dan al-gasysy, yang nota bene dilarang keras, baik oleh al-Qur'an maupun Hadis. Dengan demikian, ia merupakan al-ma siyyah, sehingga dapat dikriminalisasi melalui kategori kriminalisasi ta $z \hat{z} r$.

Lalu, di manakah letak aplikasi maslahat dalam kriminalisasi tersebut ? Untuk menemukan jawaban atas persoalan ini, perlu diberikan penjelasan tentang dasar rasionalitas kriminalisasi Pasal 8, Pasal 9, Pasal 10 huruf a, Pasal 10 huruf $\mathbf{b}$, dan Pasal 10 huruf $\mathbf{c}$ tersebut.

Kriminalisasi kelima pasal tersebut tentu punya dasar rasionalitas tersendiri. Sebagaimana diketahui, fenomena "korupsi terkait penggelapan dalam jabatan" menjadi trend (kecenderungan) yang dominan dalam jagat korupsi di Indonesia, yang pada gilirannya memberi andil luar biasa bagi dahsyatnya geliat korupsi di setiap rezim yang berkuasa sepanjang sejarah negara kita. Dengan adanya kriminalisasi melalui 5 (lima)

24 Lihat Muljatno Sindhudarmoko, (et.al), Ekonomi Korupsi, hlm. 103-123. Perhatikan pula konsiderans " Menimbang" UU Pemberantasan Tindak Pidana Korupsi yang telah dikutip. pasal di atas, geliat korupsi semacam itu dapat ditekan seminimal mungkin sehingga pada akhirnya mampu menyelamatkan keuangan dan perekonomian negara demi terwujudnya masyarakat Indonesia yang sejahtera. Sementara itu, dilihat dari sudut kualifikasi pelaku dalam varian korupsi tersebut, pelaku yang dibidik oleh kelima pasal itu adalah (a) pegawai negeri dan (b) orang non-pegawai negeri; dan ini berarti kelima pasal itu punya daya jangkau yang cukup luas, yang pada gilirannya memberi efek nir-korupsi yang optimal. Jadi, ada makna jalb al-masâlih wa dar' al-mafâsid dalam kriminalisasi kelima pasal tersebut; dan ini berarti wujud aplikasi maslahat.

Hal demikian diperkuat lagi dengan adanya kecenderungan diterapkannya secara substantif beberapa legal maxim hukum Islam berupa legal maxim "al-darar yuzâl" (segala bahaya/kerusakan harus dicegah/diberantas) dan legal maxim "yutahammal al-darar alkhâs $\underline{s}$ daf" al-darar al- âmm" (bahaya/kerusakan yang terbatas/spesifik dapat ditoleransi karena demi menghindari/memberantas bahaya/kerusakan yang meluas). ${ }^{25}$ Yang dikenai sasaran oleh ketentuan kelima pasal tersebut ialah subyek orang yang berstatus pegawai negeri dan yang tidak berstatus pegawai negeri. Manakala tindakan korupsi dibatasi hanya pada subyek orang yang berstatus pegawai negeri maka tentu orang yang tidak berstatus pegawai negeri akan selamat dari jeratan hukum korupsi; dan ini jelas menimbulkan dampak konkret yang negatif, yakni ternodainya rasa keadilan masyarakat, meningkatnya kuantitas kasus korupsi, tergerusnya kekuatan efek jera, dan melemahnya wibawa hukum. Sisi inilah yang merupakan mudarat (al-darar) yang harus dicegah dan ditanggulangi meskipun harus

25 Mengenai uraian mendalam tentang legal

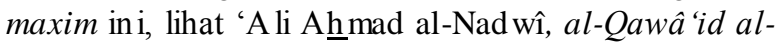
Fiqhiyyah: Mafhûmuhâ, Nasy'atuhâ, Tatawwuruhâ, Dirâsat Mu'allafâtihâ, Adillatuhâ, Muhimmatuhâ, Tatbîqâtuhâ, (Damaskus: Dâr al-Qalam, 1414 H/1994 M), hlm. 286-293. Karya ini semula merupakan disertasi penulisnya pada Program Doktor Universitas Umm al-Qurâ, Mekkah, Arab Saudi. 
mengorbankan kepentingan individu. ${ }^{26}$ Maka dari itu, hadirnya kriminalisasi dalam 5 (lima) pasal itu sesungguhnya mengandung makna penerapan legal maxim "al-darar yuzâl" dan legal maxim "yutahammal al-darar al-khâss li daf" al-darar al-'âmm". Ini jelas merupakan wujud aplikasi maslahat.

Perihal "korupsi terkait perbuatan pemerasan" diatur dalam Pasal 12 huruf e, Pasal 12 huruf g, dan Pasal 12 huruf f. Dalam perspektif hukum Islam, "korupsi terkait perbuatan pemerasan" yang diatur 3 (tiga) pasal itu dapat dirujukkan kepada perihal "perbuatan pemerasan" yang diidentifikasi oleh al-Qur'an dan Hadis sebagai akl al-mâl bi al-bâtil dan al-gasb. Dengan demikian, ia merupakan al-ma śiyyah, sehingga dapat dikriminalisasi melalui kategori kriminalisasi ta'zîr.

\section{Lalu, di mana letak aplikasi}

maslahat ? Dalam kriminalisasi ta ' $z \hat{r} r$ atas "korupsi terkait perbuatan pemerasan", wujud aplikasi maslahat harus dilihat pada segi rasionalitas kriminalisasi tersebut yang ditunjukkan sebagaimana berikut. Pertama, dalam kasus "korupsi terkait perbuatan pemerasan" itu, "pegawai negeri" atau "penyelenggara negara" diposisikan sebagai pelaku aktif sehingga hal ini menunjukkan bahwa kedudukan sebagai "pegawai negeri" atau "penyelenggara negara" memang rentan dengan perilaku koruptif yang nota bene dampaknya menggerogoti keuangan negara. Kedua, "korupsi terkait perbuatan pemerasan" merapuhkan sendi-sendi kehidupan negara, terutama keuangan/perekonomian negara, yang pada gilirannya menyengsarakan kehidupan rakyat banyak. Ketiga, "korupsi terkait perbuatan pemerasan" menimbulkan kerugian material pada diri korban "perbuatan pemerasan". Adanya kriminalisasi "korupsi terkait perbuatan pemerasan", dengan demikian, jelas mengandung makna jalb al-masâlih $\underline{h}$ wa dar' al-mafâsid, di mana kepentingan yang dilindungi ialah kepentingan masyarakat

\footnotetext{
${ }^{26}$ Perhatikan pula konsiderans "Menimbang"
} UU Pemberantasan Tindak Pidana Korupsi yang telah dikutip. luas/negara (maslahah 'âmmah). Ini jelas merupakan wujud aplikasi maslahat.

Perihal "korupsi terkait perbuatan curang" diatur dalam Pasal 7 ayat (1) huruf a, Pasal 7 ayat (1) huruf b, Pasal 7 ayat (1) huruf c, Pasal 7 ayat (1) huruf d, Pasal 7 ayat (2), Pasal 12 huruf h. Kriminalisasi "korupsi terkait perbuatan curang" yang diatur dalam 6 (enam) pasal itu jelas dapat dianalisis dengan teori maslahat. Dalam perspektif hukum Islam, secara doktriner "perbuatan curang" jelas dilarang keras dan diharamkan sebagaimana terlihat dalam pesan al-Qur'an dan Hadis. Jadi, "perbuatan curang" dikualifikasi dengan kriminalisasi ta 'zîr atas dasar alasan bahwa ia merupakan alma'siyyah. Atas dasar ini, "korupsi terkait perbuatan curang" dapat dikategorikan sebagai tindak pidana ta 'zîr.

Lalu, di mana letak aplikasi maslahat dalam kriminalisasi "korupsi terkait perbuatan curang" ini ? Hal ini dapat ditemukan melalui telaah terhadap dasar rasionalitas kriminalisasi tersebut. Secara teoritis, dasar kriminalitas ditunjukkan oleh hal-hal berikut. Pertama, dalam "korupsi terkait perbuatan curang" tersebut, "pemborong", "ahli bangunan" dan "penjual bahan bangunan" dikualifikasi sebagai pelaku aktif sehingga hal ini menunjukkan bahwa kedudukan sebagai "pemborong", "ahli bangunan", dan "penjual bahan bangunan" memang rentan dengan perilaku koruptif, misalnya kongkalingkong dengan pejabat pimpinan proyek yang tengah dikerjakan, yang nota bene dampaknya berupa penggerogotan keuangan negara. Kedua, "korupsi terkait perbuatan curang" merapuhkan sendi-sendi kehidupan negara, terutama keuangan /perekonomian negara, yang pada gilirannya menyengsarakan kehidupan rakyat banyak. Ketiga, "korupsi terkait perbuatan curang" menimbulkan kerugian pada diri korban yang terkena sasaran perbuatan. Ketiga hal tersebut jelas menggambarkan adanya penerapan jalb almasâlih wa dar' al-mafâsid sehingga aplikasi maslahat memang terwujud.

Perihal "korupsi terkait dengan benturan kepentingan dalam pengadaan" 
dimuat pada Pasal 12 huruf i. Dalam perpektif hukum Islam, perihal "benturan kepentingan dalam pengadaan" merupakan hal yang dilarang. Larangan ini dapat ditemukan melalui pesan kewajiban memelihara amanat dan keharaman mengkhianati amanat, yang terdapat dalam al-Qur'an dan Hadis. Dalam perspektif hukum pidana Islam, secara doktriner perbuatan "terkait benturan kepentingan dalam pengadaan" dapat dikriminalisasi dengan kategori kriminalisasi ta 'zîr.

Lalu, timbul pertanyaan di manakah letak aplikasi maslahat dalam kriminalisasi tersebut ? Hal ini harus ditelusuri melalui dasar rasionalitas kriminalisasi "korupsi terkait benturan kepentingan dalam pengadaan". Mengenai hal ini, dapat dikemukakan bahwa keterlibatan pegawai negeri atau penyelenggara negara dalam suatu tindak korupsi seringkali berawal dari pekerjaan pemborongan, pengadaan atau persewaan yang diurusnya atau diawasinya, di mana posisinya sebagai pengurus atau pengawas pekerjaan tersebut menciptakan iklim persaingan usaha yang tidak sehat manakala pegawai negeri atau penyelenggara negara yang bersangkutan ikut serta dalam pekerjaan tersebut karena akan terjadi benturan kepentingan. Oleh karena itu, keikutsertaan mereka harus dilarang melalui kriminalisasi. Inilah wujud maslahat dari kriminalisasi Pasal 12 huruf i. Jadi, lebih merupakan manifestasi dari sadd al-dzarî'ah yang nota bene bersendikan maslahat.

Perihal "korupsi terkait gratifikasi" diatur dalam Pasal 12B jo. Pasal 12C UU No. 20 Tahun 2001. Dalam perspektif hukum Islam, penerimaan gratifikasi (hadâya al'ummâl) dipandang sebagai bentuk al-gulûl dan haram hukumnya; dan karena itu dinilai sebagai varian al-ma'siyyah. Hal ini terkandung dalam pesan Hadis Ahmad (larangan hadiah pejabat). Dalam perspektif hukum pidana Islam, penerimaan gratifikasi (hadâya al-'ummâl) dapat dikriminalisasi, yakni dengan memasukkannya ke dalam domain kriminalisasi ta 'zîr lantaran status perbuatan "menerima gratifikasi" sebagai alma'siyyah.
Lalu, di manakah letak aplikasi maslahat ? Dalam kaitan ini, aplikasi maslahat hadir dalam bentuk dasar rasionalitasnya sebagaimana berikut. Pertama, pelarangan gratifikasi dapat menutup peluang terjadinya tindak korupsi yang lebih besar. Kedua, gratifikasi seringkali disalahgunakan untuk tujuan tindakan penyimpangan hukum. Ketiga, gratifikasi punya andil atas timbulnya feomena ekonomi berbiaya tinggi (high cost economy). Dalam format demikianlah maslahat teraplikasi dalam kriminalisasi "korupsi terkait gratifikasi".

Perihal "tindak pidana lain yang berkaitan dengan tindak pidana korupsi” diatur dalam Pasal 21, Pasal 22, Pasal 23, dan Pasal 24 UU No. 31 Tahun 1999.

Pasal 21 mengkriminalisasi "merintangi proses pemeriksaan perkara korupsi". Dalam perspektif hukum Islam, secara doktriner tindakan "mencegah, merintangi atau menggagalkan, secara langsung atau tidak langsung, penyidikan, penuntutan, dan pemeriksaan di sidang pengadilan terhadap tersangka dan terdakwa ataupun para saksi dalam perkara korupsi" (kriminalisasi versi Pasal 21) dapat dirujukkan kepada perihal larangan berbuat al-bagy yang merupakan varian al-ma śsiyyah, yang dilarang keras dan diharamkan oleh alQur'an dan Hadis.

Lalu, apakah ia dapat dikriminalisasi menurut doktrin hukum pidana Islam ? Dalam perspektif hukum pidana Islam, setiap varian al-ma'siyyah dapat dikriminalisasi; dan karena itu, tindakan "mencegah, merintangi, atau menggagalkan secara langsung atau tidak langsung penyidikan, penuntutan, dan pemeriksaan di sidang pengadilan terhadap tersangka dan terdakwa ataupun para saksi dalam perkara korupsi" dapat dikriminalisasi, di mana ia dimasukkan ke dalam kriminalisasi ta 'zîr.

Yang menjadi pertanyaan kemudian ialah di manakah letak aplikasi maslahat dalam kriminalisasi Pasal 21 tersebut ? Hal ini menuntut penjelasan tentang dasar rasionalitas kriminalisasi tersebut. Penjelasannya, tindakan "mencegah, 
merintangi, atau menggagalkan secara langsung atau tidak langsung penyidikan, penuntutan, dan pemeriksaan di sidang pengadilan dalam perkara korupsi" menimbulkan mudarat sebagai berikut. Pertama, menjatuhkan wibawa institusi peradilan pidana. Kedua, memperburuk citra dan kinerja penegakan hukum sehingga memerosotkan wibawa hukum. Ketiga, menyelamatkan lembaga peradilan dari anarki sosial. Semua itu pada gilirannya melemahkan upaya pemberantasan korupsi ke akar-akarnya. Lebih dari itu, adanya kualifikasi tindak pidana menurut Pasal 21 ("merintangi proses pemeriksaan perkara korupsi") bertujuan untuk menciptakan kelancaran proses pemeriksaan kasus tindak pidana korupsi sehingga upaya penindakan dapat berjalan efektif, yang pada gilirannya menentukan tingkat keberhasilan pemberantasan korupsi secara keseluruhan. Apalagi, jika kasus tindak pidana korupsi tersebut berhubungan dengan pejabat atau pengusaha yang berpengaruh, kecenderungan merintangi proses pemeriksaan sangat menonjol. Jadi, kriminalisasi Pasal 21 sesuai dengan prinsip jalb al-masâlih wa dar' almafâsid. Dengan demikian, jelas tergambar wujud aplikasi maslahat dalam Pasal 21 tersebut.

$$
\text { Penting untuk dipertanyakan }
$$

sejauhmanakah aplikasi maslahat dalam kriminalisasi versi Pasal 22 ? Dalam perspektif hukum Islam, secara doktriner perbuatan "tidak memberikan keterangan atau memberikan keterangan yang tidak benar" dapat dirujukkan kepada perihal "berbohong" yang merupakan perbuatan yang dilarang, sesuai dengan petunjuk alQur'an dan Hadis. Dengan demikian, dapat disimpulkan bahwa perbuatan "tidak memberikan keterangan atau memberikan keterangan yang tidak benar" adalah haram hukumnya sehingga ia merupakan alma siyyah. Dalam perspektif hukum pidana Islam, lantaran merupakan varian alma śiyyah itulah, perbuatan "tidak memberikan keterangan atau memberikan keterangan yang tidak benar" layak untuk dikriminalisasi, dan dalam hal ini yang relevan ialah kriminalisasi $t a$ ' $z \hat{\imath} r$.

Lalu, di manakah letak aplikasi maslahat dimaksud ? Mengenai hal ini dapat ditelusuri melalui dasar rasionalitas kriminalisasi versi Pasal 22. Dengan perspektif teori maslahat dapat dikatakan bahwa aplikasi maslahat sudah diaplikasikan dalam Pasal 22. Adanya kualifikasi tindak pidana versi Pasal 22 ("tidak memberi keterangan atau memberi keterangan yang tidak benar") bertujuan untuk memperoleh bukti-bukti yang sempurna, termasuk keterangan-keterangan, bagi keperluan penuntasan kasus tindak pidana korupsi yang sedang diperiksa. Karena itu, tindakan tidak memberi keterangan atau memberi keterangan yang tidak benar" dapat dikenakan pidana terhadap pelakunya. Dari sisi ini kriminalisasi Pasal 22 sudah sejalan dengan prinsip jalb al-masâlih wa dar' almafâsid. Ini jelas menggambarkan wujud aplikasi maslahat dalam Pasal 22 tersebut.

Aplikasi maslahat juga ditunjukkan oleh kualifikasi tindak pidana versi Pasal 23. Adanya kualifikasi tindak pidana menurut Pasal 23 bertujuan memberikan perlindungan hukum terhadap, baik orang yang terkait maupun harta kekayaan negara. Dalam pemeriksaan kasus korupsi, sangat dimungkinkan terjadinya penyalahgunaan kekuasaan jabatan yang merugikan pihakpihak. Oleh karena itu, diperlukan tindakan antisipatif agar tidak timbul kerugian para pihak tersebut akibat penyalahgunaan kekuasaan jabatan terkait pemeriksaan kasus korupsi. Inilah yang merupakan wujud maslahat dalam konstruksi Pasal 23. Terlihat jelas bahwa dalam kriminalisasi versi Pasal 23 telah mengandung prinsip jalb al-masâlih wa dar' al-mafâsid.

Terkait kriminalisasi versi Pasal 24 ini dapat diajukan pertanyaan sejauhmanakah aplikasi maslahat di dalamnya ? Dalam perspektif hukum Islam, secara doktriner tindakan "membuka rahasia orang lain" dapat dikorelasikan dengan sikap al-khiyânah sebagai lawan dari sikap al-amânah, sebagaimana didapatkan di dalam al-Qur'an dan Hadis. Dalam perspektif hukum pidana 
Islam, "mengkhianati amanat" (al-khiyânah) itu merupakan domain kriminalisasi ta z $z \hat{\imath}$. Dengan demikian, tindakan "membuka rahasia orang lain" yang dikriminalisasi oleh Pasal 24-dalam perspektif hukum pidana Islam-dapat dikualifikasi sebagai tindak pidana ta'zîr.

Pertanyaan yang muncul kemudian ialah di manakah letak aplikasi maslahat dalam kriminalisasi Pasal 24 tersebut ? Persoalan ini menuntut penjelasan tentang dasar rasionalitas kriminalisasi Pasal 24 itu. Setidaknya terdapat 3 (tiga) hal yang mendasari rasionalitas kriminalisasi tersebut. Pertama, terbukanya identitas pelapor akan membahayakan keselamatan jiwa si pelapor, apalagi pelaku kejahatan korupsi merupakan orang-orang yang nekad demi tercapainya cita-cita. Kedua, bila tidak dikriminalisasi, masyarakat akan merasa takut untuk melaporkan hal-hal terkait tindak pidana korupsi lantaran jiwanya senantiasa terancam bilamana identitas mereka sebagai pelapor dibuka. Ketiga, menjaga kerahasiaan identitas pelapor sangat penting untuk tercapainya efektivitas upaya pemberantasan korupsi. Lebih dari itu, adanya kualifikasi tindak pidana versi Pasal 24 bertujuan untuk melindungi keselamatan diri pelapor kasus tindak pidana korupsi. Dalam kasus korupsi yang nota bene melibatkan orang-orang berpengaruh, seringkali dilakukan berbagai cara oleh para pelakunya, termasuk cara kekerasan atau ancaman kekerasan terhadap orang yang melaporkan (pelapor) kasus korupsi tersebut, agar tindak korupsi yang diperbuatnya tidak terbongkar. Pelapor bisa saja menjadi sasaran teror sehingga kehidupan pribadi dan keluarganya terganggu, tidak nyaman dan berada dalam ancaman kekerasan. Dalam rangka mengantisipasi agar tidak terjadi hal yang demikianlah yang mendasari rasionalitas Pasal 24. Hal tersebut jelas menggambarkan adanya makna jalb al-masâlih wa dar' almafâsid. Dengan demikian, semua itu pada intinya merupakan wujud dari hifz_al-nafs dan jalb al-masâlih wa dar' al-mafâsid. Inilah wujud nyata dari aplikasi maslahat.

\section{Aplikasi Maslahat dalam Formulasi ${ }^{27}$ Sanksi Pidana}

Dalam tinjauan teori maslahat yang nota bene diakomodasi dalam doktrin hukum pidana Islam, pola pemidanaan UU Pemberantasan Tindak Pidana Korupsi di atas dapat dikualifikasi sebagai domain hukum ta 'zîr; dan ini juga merupakan konsekuensilogis dari kualifikasi tindak pidana korupsi sebagai kategori tindak pidana ta $z \hat{\imath} r$. Karena karakter fleksibilitasnya, pola pemidanaan kategori hukum pidana ta'zîr dapat diubah dan dikembangkan sesuai dengan kebutuhan dan tuntutan keadaan sehingga di dalamnya aspek rasionalitas memainkan peran yang sangat penting. Dari sisi inilah kehadiran maslahat sebagai kerangka acuan merupakan conditio sine qua non.

Pola pemidanaan UU Pemberantasan Tindak Pidana Korupsi tersebut dapat dipandang telah mengandung aplikasi maslahat berupa jalb al-masâlih wa dar' almafâsid karena pemidanaan tersebut bertujuan untuk menyelamatkan keuangan negara/perekonomian negara demi terwujudnya kesejahteraan hidup rakyat. Lebih dari itu, pola pemidanaan tersebut juga dapat dipandang telah mengakomodasi maslahat, yakni membela kepentingan rakyat banyak dengan melindungi harta kekayaan negara dari penggerogotan para koruptor melalui penetapan sanksi pidana yang adil dan efektif. Hal ini sejalan dengan salah satu komponen maslahat, yakni hif $\underline{z}$ al-mâl, di mana kepentingan yang dilindungi ialah kepentingan hidup rakyat/negara (maslahah 'âmah).

Dalam perspektif hukum pidana Islam, bentuk-bentuk pidana dalam UU Pemberantasan Tindak Pidana Korupsi juga dapat dipandang telah mengandung maslahat. Secara teoretis, diakui bahwa penentuan bentuk pidana terhadap suatu macam tindak pidana korupsi-sebagaimana diintrodusir UU Pemberantasan Tindak Pidana Korupsi-telah mempertimbangkan aspek rasionalitas yang,

27 Kata "formulasi" mengandung arti: perumusan. Lihat Pusat Bahasa-Depdiknas, Kamus Besar Bahasa Indonesia, (Jakarta: Balai Pustaka, 20005), Ed isi Ketiga, hlm. 320. 
antara lain, berupa tujuan pemidanaan, efektivitas pidana, dan social costs analysis. Dalam hal tujuan pemidanaan, dapat dikatakan bahwa UU Pemberantasan Tindak Pidana Korupsi telah mempertimbangkan (a) tujuan prevensi, yakni mencegah dilakukannya tindak pidana; (b) tujuan resosialisasi dan rehabilitasi, yakni memasyarakatkan terpidana dengan mengadakan pembinaan sehingga menjadi orang yang baik dan berguna; (c) tujuan reformasi sosial, yakni menyelesaikan konflik yang ditimbulkan oleh tindak pidana, memulihkan keseimbangan, dan mendatangkan rasa damai dalam masyarakat. ${ }^{28}$ Dalam hal efektivitas pidana, pidana penjara dan pidana denda-hingga kinimasih diterapkan dalam berbagai sistem hukum pidana yang berlaku di segenap penjuru dunia; dan ini berarti pidana penjara diakui efektivitasnya. Dalam hal social costs analysis, pidana penjara dan pidana denda membawa efek berupa keuntungan sosial yang nota bene relatif mengungguli kerugian sosial yang ditimbulkannya. Hal demikian inilah yang merupakan wujud aplikasi maslahat dalam formulasi bentuk-bentuk pidana dalam UU Pemberantasan Tindak Pidana Korupsi, apalagi mengingat sanksi pidana bagi tindak pidana korupsi masuk domain hukum ta 'zîr, yang nota bene bersifat dinamis, relatif dan fleksibel. Dalam kaitan ini, pemidanaan diberikan atas nama negara; ia "diotorisasikan". Maksudnya, setiap pemidanaan harus datang dari institusi negara yang berwenang secara hukum. ${ }^{29}$

Dalam kaca mata hukum pidana Islam, aturan pidana tambahan dalam UU Pemberantasan Tindak Pidana Korupsi juga merepresentasikan penerapan maslahat.

${ }^{28}$ Lihat Muhammad Abu Zahrah, al-'Uqûbah fi al-Fiqh al-Islâmiy, (Kairo: Dâr al-Fikr al-'Arabiy, 1998), h. 22-38. Lihat juga Muhammad Fathi Bahnasi, al-'Uqûbah fi al-Fiqh al-Islâmiy, (Beirut: Dâr alSyurûq, 1983), h. 14-19; dan 'Abd al-Qâdir 'Audah, al-Tasyrî' al-Jinâ'iy al-Islâmiy, (Be irut: Mu'assasat alRisâlah, 1998), Juz ke-1, h. 608-611.

${ }^{29}$ Lihat 'Abd al-'A zîz Hindi, A $\underline{d} w \hat{a}$ ' ' 'ala Taqnîn al-Syarî'ah al-Islâmiyyah: al-Jarîmah wa al'Iqâb fi al-Syarî'ah al-Islâmiyyah, (Kairo: Dâr alHidâyah, Dâr al-Sahwwah, t.th.), hlm. 27-33.
Secara teoretis, diakui bahwa aturan pidana tambahan tersebut telah mempertimbangkan aspek rasionalitas, yakni didasarkan pada tujuan pemidanaan berupa pemenuhan rasa keadilan masyarakat dan sarana perlindungan masyarakat. Hal ini jelas merupakan wujud dari komponen maslahat, yakni jalb almasâlih wa dar' al-mafâsid, di mana kepentingan yang dilindungi ialah kepentingan hidup masyarakat (maslahah 'ammah). Ini merupakan bentuk aplikasi maslahat dalam formulasi aturan pidana tambahan dalam UU Pemberantasan Tindak Pidana Korupsi.

Dalam perspektif hukum pidana Islam, penetapan pidana denda terhadap korporasi dalam kasus tindak pidana korupsi dapat dipandang telah mengakomodasi teori maslahat. Wujud maslahat itu ditunjukkan dengan adanya rasionalitas yang mendasari penetapan denda. Hal ini menggambarkan aplikasi maslahat dalam formulasi aturan pidana tambahan dalam UU Pemberantasan Tindak Pidana Korupsi.

Dalam pandangan hukum pidana Islam, penetapan ancaman pidana minimal khusus bagi varian-varian tindak pidana korupsi merupakan kebijakan yang masuk dalam domain hukum ta'zîr, di mana maslahat dijadikan kerangka acuan dalam formulasinya. Dalam kaitan ini, maslahat mewujud dalam bentuk manfaat yang diperoleh hakim berupa patokan untuk menjatuhkan pidana sehingga putusan yang dibuat dapat lebih mendekati rasa keadilan masyarakat.

\section{Aplikasi Maslahat dalam Konsepsi ${ }^{30}$ Pertanggungjawaban Pidana Korporasi}

Dalam doktrin hukum pidana Is lam, is u pertanggungjawaban pidana memang berkait erat dengan isu subyek hukum (al-mahkûm 'alaih); dan ini berarti berhubungan langsung dengan isu al-taklîf dan isu al-ahliyyah, di mana isu-isu tersebut merupakan domain

${ }^{30}$ Kata "konsepsi" mengandung arti: rancangan pikiran, pendapat, paham, pengertian yang telah dituangkan. Lihat Pusat Bahasa-Depdiknas, Kamus Besar Bahasa Indonesia, (Jakarta: Balai Pustaka, 20005), Edisi Ketiga, hlm. 588. 
disiplin uŝ̂ul al-fiqh (teori hukum Islam). ${ }^{31}$ Dalam kajian usûl al-fiqh, yang diposisikan sebagai subyek hukum ialah manusia, orang (al-insân). Sebelum memiliki kualitas pertanggungjawaban pidana, setiap orang harus terlebih dahulu memperoleh kualitas cakap hukum (al-ahliyyah). ${ }^{32}$ Sedangkan kualitas cakap hukum (al-ahliyyah) bisa diperoleh hanya jika orang itu memenuhi persyaratan: al- âqil dan al-bâlig. Syarat al'âqil mengandung arti kesempurnaan fungsional akal sehat, sedang syarat al-bâlig menunjuk kepada arti kematangan usia, yang ditandai dengan pencapaian usia 17 tahun atau pernah bermimpi jimak atau sudah kawin. ${ }^{33}$ Apabila persyaratan tersebut terpenuhi pada diri seseorang, barulah ia dikatakan sebagai orang yang cakap hukum (punya kualitas al-ahliyyah), dan karenanya ia telah memiliki kualitas pertanggungjawaban pidana (al-mas'ûliyyah al-jinâ'iyyah).

Perlu diperhatikan bahwa dalam doktrin hukum Islam, pertanggungjawaban hukumyang salah satu bentuknya berupa pertanggungjawaban pidana-berkait erat dengan isu teologis, yakni perihal doktrin alhisâb di hadapan mahkamah Allah kelaksuatu hal yang membedakan sistem hukum Islam dengan sistem hukum sekuler. Maka dari itu, yang bisa dimintai pertanggungjawaban hanyalah manusia atau orang.

Atas dasar demikian, doktrin hukum pidana Islam menetapkan bahwa kualitas pertanggungjawaban pidana pada dasarnya dimiliki oleh manusia atau orang. Ini

31 Lihat 'Ali Hasaballah, Usîul al-Tasyrî' alIslâmiy, (Mesir: Dâr al-Ma ârif, 1383 H/1964 M), hlm. 354-359; dan 'Abd al-Wahhâb Khallâf, 'Ilm Usîul alFiqh, (Kuwait: al-Dâr al-Kuwaitiyyah, 1388 H/1968 M), hlm. 134-140.

${ }^{32}$ Lihat Wahbah al-Zuhailiy, Usûul al-Fiqh alIslâmiy, (Beirut: Dâr al-Fikr, 1406 H/1986 M), hlm.

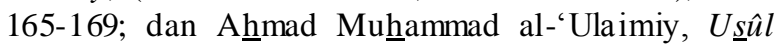
al-Fiqh: Asâsiyyât wa Mabâdi', (Beirut: Dâr Ibn Hazm, 1422 H/2001 M), hlm. 48-51.

33 Lihat Muhammad al-Khudari Bik, Usîul alFiqh, (Beirut: Dâr al-Fikr, 1409 H/1988 M), hlm. 8693; dan Muhammad Abû Zahrah, Usîul al-Fiqh, (Kairo: Dâr al-Fikr al- 'Arabiy, 1377 H/1958 M), hlm. 327-328. merupakan asas individualitas pertanggungjawaban pidana (syakhsiyyat almas'ûliyyah al-jinâ'iyyah), yang dianut sistem hukum pidana Islam. ${ }^{34}$ Namun, dalam perkembangan dunia hukum pada abad kontemporer ini muncul isu kejahatan korporasi (corporate crime). Dalam kasus kejahatan korporasi, pelaku aktual-riil adalah manusia atau orang yang bertindak untuk atau atas nama korporasi atau untuk kepentingan korporasi. Lalu, bagaimanakah doktrin hukum pidana Islam merespon isu ini ?

Dalam mengeksplorasi pandangan hukum pidana Islam tersebut, perlu dipahami terlebih dahulu apa fungsi kehadiran aturan pidana dalam sistem hukum pidana. Secara normatif-doktriner, aturan pidana-dalam sistem hukum pidana-hadir dalam rangka menjalankan fungsi preventif dan fungsi represif. Seperti telah dikemukakan, dalam kasus kejahatan korporasi, yang menjadi aktor aktual ialah manusia atau orang yang bertindak untuk atau atas nama korporasi atau untuk kepentingan korporasi, sedang korporasi menjadi aktor formal. Oleh karena itu, sanksi hukum yang ditetapkan tertuju kepada kedua aktor dari kejahatan yang telah dilakukan, yaitu aktor aktual dan aktor formal. Bagi aktor aktual ditetapkan sanksi pidana pokok berupa pidana penjara dan pidana denda. Sedangkan terhadap aktor formal ditentukan sanksi pidana pokok berupa pidana denda, dan pidana tambahan berupa (a) pencabutan izin usaha, (b) perampasan kekayaan hasil tindak pidana, (c) pencabutan status badan hukum, (d) pemecatan pengurus, dan /atau (e) pelarangan kepada pengurus tersebut untuk mendirikan korporasi dalam bidang usaha yang sama. Dari paparan di atas nampak jelas bahwa dalam kasus kejahatan korporasi, yang bertanggung jawab secara hukum sesungguhnya manusia atau orang, sehingga orang atau individu itu jugalah yang akan dimintai pertanggungjawaban (yang bersifat ukhrawi) di hadapan mahkamah Allah di

34 Ahnmad Fathi Bahnasi, al-Mas'ûliyyah alJinâ'iyyah fi al-Fiqh al-Islâmiy, (Kairo: Dâr alQalam, t.th.), hlm. 34-36. 
akhirat kelak. Sedangkan korporasi sebagai aktor formal tetap dimintai pertanggungjawaban yang bersifat duniawi (syakhsiyyah ma'nawiyyah) ${ }^{35} \mathrm{demi}$ memenuhi rasa keadilan. Jadi, dari titik pandang ini, aturan pertanggungjawaban pidana korporasi dalam tindak pidana perdagangan manusia sudah sejalan dengan doktrin hukum pidana Islam.

Yang harus dikuak lebih jauh ialah sejauhmanakah maslahat teraplikasi dalam konsepsi pertanggungjawaban pidana korporasi tersebut. Hal ini dapat dijelaskan sebagai berikut. Pertama, ketentuan keharusan adanya pertanggungjawaban pidana korporasi dapat mengeliminasi tingk at kecenderungan modus kejahatan modernterutama korupsi-dengan kamuflase 'ketiadaan subyek orang' agar bebas dari kejaran hukum. Kedua, pemidanaan terhadap korporasi sebagai subyek hukum pidana tersebut bertujuan menciptakan keadilan dan kepastian hukum di tengah-tengah kehidupan bermasyarakat, berbangsa dan bernegara. Ketiga, sanksi-sanksi pidana yang ditetapkan bagi korporasi berpotensi menjadi sumber dana negara untuk mensejahterakan masyarakat.

\section{Penutup}

Dari uraian di atas dapat disimpulkan bahwa bahwa teori maslahat memiliki relevansi dengan UU Pemberantasan Korupsi. Dapat disimpulkan pula bahwa adanya relevansi yang demikian membawa implikasi bahwa hukum pidana Islam telah mengalami transformasi atau objektivikasi melalui aplikasi maslahat ke dalam tatanan hukum pidana nasional, yang pada gilirannya mencerminkan integrasi Hukum Agama (Islam) ke dalam Hukum Negara. Adanya relevansi yang demikian juga membawa implikasi bahwa perundang-undangan pidana khusus di Indonesia telah mengalami islamisasi melalui aplikasi maslahat dalam norma-norma yang dikand ungnya.

Kesimpulan tersebut didukung dengan bukti-bukti sebagai berikut. Pertama, aplikasi

${ }^{35}$ Lihat Ibrahim Hosen, Filsafat Hukum Islam, (Jakarta: Yayasan IIQ, 1997), hlm. 32-34. maslahat telah terbukti dalam aspek kriminalisasi yang terdapat di dalam UU Pemberantasan Tindak Korupsi. Kedua, aplikasi maslahat juga telah terbukti dalam aspek formulasi sanksi pidana yang tertuang di dalam UU Pemberantasan Korupsi. Ketiga, aplikasi maslahat juga telah terbukti dalam konsepsi pertanggungawaban pidana korporasi yang diatur oleh UU Pemberantasan Korupsi.

Atas dasar kesimpulan di atas, dipandang perlu untuk terus melakukan kajian tentang aplikasi teori maslahat dalam konteks kebijakan hukum pidana agar semakin kuat bukti bahwa hukum pidana Islam memang compatible dengan konteks keindonesiaan dan kemodernan. Kajian tersebut juga layak diintensifkan di kalangan perguruan tinggi Islam sehingga mampu diperoleh kontribusi ilmiah yang memadai dalam rangka "islamisasi hukum pidana nasional" atau "nasionalisasi hukum pidana Islam" melalui aplikasi teori maslahat. Melalui kajian tersebut juga diharapkan timbulnya pemahaman di kalangan umat Islam-terutama kelompok yang sangat antusias dan ambisius dengan formalisasi Syariah Islam-bahwa hukum pidana Islam sudah dan dapat diterapkan di Indonesia melalui pintu aplikasi teori maslahat dengan strategi transformasi, kontekstualisasi dan objektivikasi, tanpa perlu mendirikan "Negara Islam" atau menjadikan "Islam sebagai Dasar Negara"-sesuatu yang dicitacitakan oleh eksponen gerakan/ormas Islam tertentu. 


\section{DAFTAR PUSTAKA}

Al-Qur'an dan Terjemahnya, Departemen Agama RI, 2000

'Âmir, 'Abd al-'Azîz, al-Ta'zîr fi alSyarî'ah al-Islâmiyyah, Beirut: Dâr alFikr al-'Arabiy, t.th.

'Atiyyah, Jamâl al-Dîn, Nahlwa Taf'îl Maqâsid al-Syarî'ah, Damaskus: Dâr al-Fikr, 2001

'Audah, 'Abd al-Qâdir, al-Tasyrî' al-Jinâ'iy al-Islâmiy Muqâranan bi al-Qânûn alWad 'iy, Beirut: Mu’assasat al-Risâlah, 1998 M/1419 H

Abdillah, Masykuri, Demokrasi yang Religius: Membincang Kembali Konsep Demokrasi di Indonesia, Jakarta: UIN Syarif Hidayatullah, 2004, Naskah Pidato Pengukuhan Guru Besar dalam Fiqh Siyasah (Ilmu Politik Islam), (tidak diterbitkan).

Abû Zahrah, Muhammad, al-Jarîmah wa al'Uqûbah fi al-Fiqh al-Islâmiy: alJarîmah, Dâr al-Fikr, 1998

Abû Zahrah, Muhammad, al-Jarîmah wa al'Uqûbah fi al-Fiqh al-Islâmiy: alUqûbah, Dâr al-Fikr, 1998

Adji, Oemar Seno, Hukum (Acara) Pidana dalam Prospeksi, Jakarta: Erlangga, 1976

Arief, Barda Nawawi, Bunga Rampai Kebijakan Hukum Pidana, Jakarta: Citra Aditya Bakti, 2002

-----, Kapita Selekta Hukum Pidana, Bandung: Citra Aditya Bakti, 2003

-----, Kebijakan Legislatif dalam Penanggulangan Kejahatan dengan Pidana Penjara, Semarang: Badan Penerbit Universitas Diponegoro, 2000

------, Masalah Penegakan Hukum dan Kebijakan Hukum Pidana dalam Penanggulangan Kejahatan, Jakarta: Kencana Prenada Media, 2008

------, Pembaharuan Hukum Pidana dalam Perspektif Kajian Perbandingan, Bandung: Citra Aditya Bakti, 2005
Arief, Basrief, Korupsi dan Upaya Penegakan Hukum (Kapita Selekta), Jakarta: Adika Remaja Indoneisa, 2006

Asshiddiqie, Jimly, Pembaharuan Hukum Pidana Indonesia: Studi tentang Bentuk-Bentuk Pidana dalam Tradisi Hukum Fiqh dan Relevansinya bagi Usaha Pembaharuan KUHP Nasional, Band ung: Penerbit Angkasa, 1996

Atmasasmita, Romli, (et.al), Pengkajian Hukum tentang OECD Convention on Combating Bribery of Foreign Public Officials International Business Transaction, Jakarta: Badan Pembinaan Hukum Nasional, Departemen Kehakiman dan HAM RI, 2003

al-'Awwâ, Muhammad Salîm, Fi U $\underline{s u ̂ l}$ alNizâm al-Jinâ'iy al-Islâmiy: Dirâsah Muqâranah, Kairo: Dâr al-Ma'ârif, t.th.

Bahnasi, Ahmad Fathi, al-'Uqûbah fi al-Fiqh al-Islâmiy, Beirut: Dâr al-Syurûq, 1403 $\mathrm{H} / 1983 \mathrm{M}$

-----, al-Mas'ûliyyah al-Jinâ'iyyah fi al-Fiqh al-Islâmiy, Kairo: Dâr al-Qalam, t.th

------, Madkhâl al-Fiqh al-Jinâ 'iy al-Islâmiy, Beirut, Kairo: Dâr al-Syurûq, t.th

Bakri, Asafri Jaya, Konsep Maqâsidd alSyarî'ah Menurut al-Syâtibi, Jakarta: RajaGrafindo Persada, 1996

Bassiouni, M. Cherif, “ Qesas Crimes “, dalam M. Cherif Bassiouni, (ed.), The Islamic Criminal Justice System, New York: Oceana Publications, Inc., 1982

Burhan, A.S., (et.al), (eds.), Korupsi di Negeri Kaum Beragama: Ikhtiar Membangun Fiqh Anti-Korupsi, Jakarta: P3M dan KemitraanPartnership, 2004

al-Bûti, Muhammad Sa'îd Ramadân, Dawâbit al-Mas lahah fi al-Syarî'ah alIslâmiyyah, Beirut: Mu'assasat alRisâlah, 1421 H/2000 M

Chazawi, Adami, Hukum Pidana Materiil dan Formiil Korupsi di Indonesia, Jakarta: Bayumedia Publishing, 2005

Departemen Agama, Rencana Aksi Nasional Pemberantasan Korupsi dengan 
Pendekatan Agama, Monitoring dan Evaluasinya di Lingkungan Departemen Agama Tahun 2006-2009, Jakarta: Inspektorat JenderalDepartermen Agama, 2006

Farid, A.Z.Abidin, Andi Hamzah, BentukBentuk Khusus Perwujudan Delik (Percobaan, Penyertaan dan Gabungan Delik) dan Hukum Penitensier, Jakarta: Raja Grafindo Persada, 2006.

Fâsiy, 'Allâl al-, Maqâsid al-Syarî'ah alIslâmiyyah wa Makârimuha, Rabat: Maktabah al-Wihdah al-'Arabiyyah, t.th.

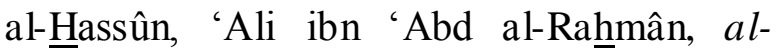
'Uqûbât al-Mukhtalaf alaîhâ fi Jrâ'im al-Hudûd, Riyad: Dâr al-Nafâ' is, 1422 $\mathrm{H} / 2001 \mathrm{M}$

Hamzah, Andi, Pemberantasan Korupsi Melalui Hukum Pidana Nasional dan Internasional, Jakarta: Raja Grafindo Persada, 2006

Hartanti, Eva, Tindak Pidana Korupsi, Jakarta: Sinar Grafika, 2008

Hindi, 'Abd al- 'Azîz, Ad $\underline{d}$ â' 'ala Taqnîn alSyarî'ah al-Islâmiyyah: al-Jarimah wa al-'Iqâb fi al-Syarî'ah al-Islâmiyyah, Kairo: Dâr al-Hidâyah, Dâr al- $\underline{\text { Sahwah, }}$ t.th.

Hisân, Husain Hâmid, Fiqh al-Maslahah wa Tatbîqâtuhu al-Mu'âsirah, dalam International Seminar on Fundamental Structure of Contemporary Islamic Economy, Jeddah: IRTI-Islamic Development Bank, Ramâdan, 1413 H. (tidak diterbitkan).

Hisân, Husain Hâmid, Nazariyyat alMaślahah fi al-Fiqh al-Islâmiy, Beirut: Dâr al-Nahdah al- 'Arabiyyah, 1971

Hosen, Ibrahim, Filsafat Hukum Islam, Jakarta: Yayasan IIQ, 1997

Ibn Rabî'ah, 'Abd al-'Azîz ibn 'Abd alRahmân, 'Ilm Maqâsid al-Syâri' , Riyad : Maktabah Malik Fahd alWataniyyah, 2002

Ibn Sinân, Muhammad ibn 'Ali, al-Jânib alTa 'zîriy fi Jârîmat al-Zinâ, t.tp.: t.np, $1402 \mathrm{H} / 1982 \mathrm{M}$
Jaffâl, 'Ali Dâwud Muhammad, al-Taubah wa Atsaruhâ fi Isqât al- $\underline{H} u d \hat{u} d$ fi alFiqh al-Islâmiy, Beirut: Dâr al-Nahdah al-'Arabiyyah, 1409 H/1989 M

Kartanegara, Satochid, Hukum Pidana: Kumpulan Kuliah, Jakarta: Balai Lektor Mahasiswa Universitas Indonesia, t.th

Komisi Pemberantasan Korupsi (KPK), Memahami untuk Membasmi: Buku Saku untuk Memahami Tindak Pidana Korupsi, Jakarta: KPK, 2006

Kuntowijoyo, Identitas Politik Umat Islam, Bandung: Mizan, 1999

al-Kailâni, 'Abd al-Rahmân Ibrâhîm Zaid, Qawâ id al-Maqâsid 'ind al-Imâm alSyâtibi 'Aradan wa Dirâsatan wa Tahlîlan, Damaskus; Dâr al-Fikr, 2000

al-Kamâli, 'Abdullah Yahya, Maqâsid alSyarî'ah fi Dau' Fiqh al-Muwâzanât, Beirut: Dâr Ibn 프르, 1421 H/2000 M

Lopa, Baharuddin, Kejahatan Korupsi dan Penegakan Hukum, Jakarta: Penerbit Buku Kompas, 2001

Loqman, Loebby, “ Tanggung jawab Pidana Korporasi dalam Tindak Pidana Lingkungan ", dalam Jurnal Hukum dan Pembangunan, 1989:3, Tahun XIX, Juni 1989

al-Luhaibi, Mutî‘ullah ibn Dakhîlullah ibn Sulaimân, al- 'Uqûbât al-Tafwîldiyyah wa Ahdâfuha fi Dau' al-Kitâb wa alSunnah, Jeddah: Tihâmah, 1404 H/1983 $\mathrm{M}$

Majelis Tarjih dan Tajdid PP Muhammadiyah, Fikih Anti-Korupsi: Perspektif Ulama Muhammadiyah, Jakarta: PSAP, 2006

Mas'udi, Masdar F., " Meletakkan kembali Maslahah sebagai Acuan Syariat ", dalam Zuhairi Misrawi, Menggugat Tradisi : Pergulatan Pemikiran Anak Muda NU, Jakarta: Penerbit Buku Kompas, 2004

Masud, Muhammad Khalid, Islamic Legal Philosophy : A Study of Abu Ishaq alSyathibi's Life and Thought, New Delhi: International Islamic Publishers, 1977 
Minarno, Nur Basuki, Penyalahgunaan Wewenang dan Tindak Pidana Korupsi dalam Pengelolaan Keuangan Daerah, Yogyakarta: Laksbang Mediatama, 2009

Moeljatno, Asas-Asas Hukum Pidana, Jakarta; Rineka Cipta, 2002

Muladi, Barda Nawawi Arief, Bunga Rampai Hukum Pidana, Bandung: Alumni, 1992

------, dan Barda Nawawi Arief, Teori-Teori dan Kebijakan Pidana, Bandung: Alumni, 1998

Muslehuddin, Muhammad, Philosophy of Islamic Law and The Orientalists, New Delhi: Markazi Maktaba Islami, 1985

al-Nadwi, 'Ali Ahmad, al-Qawâ'id alFiqhiyyah: Mafhûmuhâ, Nasy'atuhâ, Tatawwuruhâ, Dirâsat Mu'allafâtihâ, Adillatuhâ, $\quad$ Muhimmatuhâ, Tatbîqâtuhâ, Damaskus: Dâr al-Qalam, 1414 H/1994 M

al-Namlah, 'Abd al-Karîm ibn 'Ali ibn Muhammad, Itsbât al-'Uqûbât bi alQiyâs, Riyad: Maktabah al-Rusyd, $1410 \mathrm{H}$

Naim, Muhammad Masyhuri, (et.al), $N U$ Melawan Korupsi: Kajian Tafsir \& Fiqih, Jakarta: Tim Kerja Gerakan Nasional Pemberantasan Korupsi-PB NU, 2006

Nitibaskara, Tb. Ronny Rahman, Tegakkan Hukum, Gunakan Hukum, Jakarta: Penerbit Kompas, 2006

Opwis, Felicitas, "Maslaha in Contemporary Islamic Legal Theory “, dalam Journal Islamic Law and Society, Vol. 2, No. 12, 2005, Koninklijke Brill NV, Leiden, 2005

Poernomo, Bambang, Asas-Asas Hukum Pidana, Jakarta: Ghalia Indonesia, 1994

Prodjodikoro, Wirjono, Asas-Asas Hukum Pidana di Indonesia, Bandung: Eresco, 1989

al-Qaradawi, Yusuf, Fiqih Maqashid Syariah: Moderasi Islam antara Aliran Tekstual dan Aliran Liberal, terj. Arif
Munandar Riswanto, Jakarta: Pustaka Al-Kautsar, 2007

al-Qaradawi, Yusuf, Madkhal li Dirâsat alSyarî'ah al-Islâmiyyah, Kairo: Maktabah Wahbah, 1421 H/2001 M

al-Raḥmân, Jalâl al-Dîn 'Abd, al-Maśâliḥ alMursalah wa Makânatuhâ fi al-Tasyrî̀ al-Islâmiy, Kairo: Dâr al-Kitâb alJâmi‘iy, 1403 H/1983 M

al-Raisunî, Ahmad, Nazzariyyat al-Maqâsid 'inda al-Imâm al-Syâtibi, Riyad: al-Dâr al-'Âlamiyyah li al-Kitâb al-Islâmiy, 1995

Reid, Sue Titus, Criminal Law, New York: McGraw-Hill Higher Educ ation, 2001

Sahetapy, J.E. , Kejahatan Korporasi, Bandung: Refika Aditama, 2002

Saleh, Roelan, Perbuatan Pidana dan Pertanggungjawaban Pidana: Dua Pengetahuan Dasar dalam Hukum Pidana, Jakarta: Aksara Baru, 1983

Sapardjaja, Komariah Emong, Ajaran Sifat Melawan-Hukum Materiil dalam Hukum Pidana Indonesia: Studi Kasus tentang Penerapan dan Perkembangannya dalam Yurisprudensi, Bandung: Alumni, 2002

Senoadjie, Indriyanto, Korupsi dan Hukum Pidana, Jakarta: Kantor Pengacara dan Konsultan Hukum Prof. Oemar Seno Adji \& Rekan, 2001

Sudarto, Hukum dan Hukum Pidana, Bandung: Alumni, 1986

Suratmaputra, Ahmad Munif, Filsafat Hukum Islam al-Ghazali: Mas lahah Mursalah dan Relevansinya dengan Pembaharuan Hukum Islam, Jakarta: Pustaka Firdaus, 2002

al-Syâtibi, Abû Ishâq Ibrâhîm, al-Muwâfaqât fi Usîl al-Syarî'ah, Beirut: Dar alKutub al-'Ilmiyyah, t.th.

Syuhbah, Muhammad ibn Muhammad Abû, al- $\underline{\text { Hudûd }}$ fi al-Islâm wa Muqârantuha bi al-Qawânîn al-Wad 'iyyah, Kairo: alHai' ah al- 'Âmmah li Syu'ûn al-Matâbi' al-Amîriyyah, 1394 H/1974 M 
Tâhir ibn 'Âsyûr, Maqâsid al-Syarî'ah alIslâmiyyah, Tunis: Dâr Suhnun, Kairo: Dar al-Salâm, 1427 H/2006 M

al-Tûfi, Najm al-Dîn, Syarh al-Arba'în alNawawiyyah, lampiran dalam Mustafa Zaid, al-Maslahah fi al-Tasyrî' alIslâmiy wa Najm al-Dîn al-Tûfi, t.tp.: Dâr al-Fikr al-'Arabiy, 1384 H/1964 M

UU RI No. 31 Tahun 1999 tentang Pemberantasan Tindak Pidana Korupsi

UU RI No. 20 Tahun 2001 tentang Perubahan atas UU RI No. 31 Tahun 1999 tentang Pemberantasan Tindak Pidana Korupsi

UU RI No. 30 Tahun 2002 tentang Komisi Pemberantasan Tindak Pidana Korupsi
Wahbah, Taufîq 'Ali, al-Tadâbîr alZajriyyah wa al-Wiqâ'iyyah fi alTasyrî̀ al-Islâmiy wa Uslûb Tațbîqiha, Riyad: Dâr al-Liwâ', 1401 H/1981 M

Wiyono, R., Pembahasan Undang-Undang Pemberantasan Tindak Pidana Korupsi, Jakarta: Sinar Grafika, 2006

Zaid, Mustafa, al-Mas lahah fi al-Tasyrî‘ alIslâmiy wa Najm al-Dîn al-Thufi, Kairo: Dâr al-Fikr al-'Arabiy, 1384 H/1964 M

al-Zarqâ, Mustafa Ahmad, al-Istis $\underline{\text { lâh }} \underline{\text { w wa al- }}$ Maśâlin al-Mursalah fi al-Syarî'ah alIslâmiyyah wa Usîl Fiqhiha , Damaskus: Dâr al-Qalam, 1988 